\title{
POTENSI ANTIINFLAMASI EKSTRAK DAUN TAHONGAI (Kleinhovia hospita L)
}

\author{
Tias Puspita Sari ${ }^{1, *}$, Laode Rijai ${ }^{1}$, Sabaniah Indjar Gama ${ }^{1}$ \\ ${ }^{1}$ Laboratorium Penelitian dan Pengembangan "FARMAKA TROPIS” Fakultas Farmasi Universitas \\ Mulawarman, Samarinda, Kalimantan Timur \\ *Email: tyaspuspita25@gmail.com
}

\begin{abstract}
Tahongai plants (Kleinhovia hospita L) are one of many various of plant that spread widely in East Kalimantan especially in Samarinda. In an empirically tahongai leaves are used as a hepatoprotector and used to healing the degenerative diseases. Inflammation is a response for tissue caused by chemical reaction, mechanical or microorganism infection. This research significant are to knowing the activity ang the potential tahongai as antiinflammatiion, using paw edema method with carrageenan inductans $1 \%$ on white mice that grouped into five. Those five categorize are negative control ( $\mathrm{Na} \mathrm{CMC}$ ), positive control (Na diclofenac) and given extract with some dose around $250 \mathrm{mg} / \mathrm{kg}, 500 \mathrm{mg} / \mathrm{kg}$ and $750 \mathrm{mg} / \mathrm{kg}$. The edema volume measuring volume do in every hour for nine hours using pletismometer instrument. The results of those measuring will be present based on the average of swollen volume descriptively. Based on the research, tahongai leaves extract have activity as antiinflamation, the best dose as antiinflamation is $750 \mathrm{mg} / \mathrm{kgBB}$, it is also has potential antiinflamation that almost same with positive control $\mathrm{Na}$ Diclofenak.
\end{abstract}

Key Word: Kleinhovia hospita L, Paw Edema, Antiinflamatory

\begin{abstract}
ABSTRAK
Tumbuhan tahongai (Kleinhovia hospita L) merupakan salah satu tumbuhan yang tersebar luas di Kalimantan Timur salah satunya di Samarinda. Secara empiris daun tahongai digunakan sebagai hepatoprotektor dan untuk menyembuhkan penyakit degeneratif. Inflamasi merupakan respon terhadap kerusakan jaringan akibat rangsangan kimia, mekanis maupun infeksi oleh mikroorganisme. Penelitian ini bertujuan untuk mengetahui aktivitas dan potensi daun tahongai sebagai antiinflamasi menggunakan metode paw edema dengan penginduksi karegenan $1 \%$ pada tikus putih yang dikelompokkan menjadi lima kelompok yaitu kontrol negatif ( $\mathrm{Na} \mathrm{CMC}$ ), kontrol positif (Na diklofenak) dan diberikan ekstrak dengan dosis $250 \mathrm{mg} / \mathrm{kgBB}, 500 \mathrm{mg} / \mathrm{kgBB}$ dan $750 \mathrm{mg} / \mathrm{kgBB}$. Pengukuran volume edema dilakukan setiap 1 jam selama 9 jam menggunakan instrument pletismometer. Hasil pengukuran disajikan berdasarkan data rata-rata volume bengkak secara deskriptif. Berdasarkan hasil pengamatan, ekstrak daun tahongai menunjukan aktivitas terbaik sebagai antiinflamasi pada dosis $750 \mathrm{mg} / \mathrm{kgBB}$.
\end{abstract}

Kata Kunci : Kleinhovia hospita L, Paw Edema, Antiinflamasi

\section{PENDAHULUAN}

Inflamasi merupakan suatu respon protekstif normal terhadap luka jaringan yang disebabkan oleh trauma fisik, zat kimia yang merusak atau zat-zat mikrobiologik. Inflamasi juga merupakanusaha tubuh untuk menginaktivasi atau merusak organisme yang 
menyerang, menghilangkan zat iritan, dan mengatur derajat perbaikan jaringan. Jika terjadi proses penyembuhan maka biasanya peradangan akan mereda (Mycek, 2010)

Pada proses inflamasi terjadi reaksi vaskuler, sehingga cairan, elemen-elemen darah, sel darah putih (leukosit) dan mediator kimia terkumpul pada tempat yang cedera untuk menetralkan dan menghilangkan agen-agen berbahaya serta untuk memperbaiki jaringan yang rusak (Kee dan Hayes, 1996). Tanda- tanda inflamasi meliputi kerusakan mikrovaskuler, peningkatan permeabilitas kapiler dan migrasi leukosit ke daerah inflamasi (Wilmana,1995).

Pengobatan inflamasi mempunyai dua tujuan utama. Pertama meringankan nyeri yang merupakan gejala awal yang terlihat dan yang kedua memperlambat atau membatasi proses perusakan jaringan.Obat-obat antiinflamasi non steroid dan kortikosteroid sama-sama memiliki kemampuan untuk menekan tanda dan gejala inflamasi, namun kedua obat obat golongan ini seringkali menimbulkan efek berbahaya dan merugikan (Katzung 2002). Oleh karena tu pemanfaatan tumbuhan obat dengan khasiat antiinflamasi perlu dilakukan untk menemukan alternatif pengobatan dengan efek samping yang relatif lebih kecil.

Daun tahongai (Kleinhovia hospita $L$ ) atau yang lebih dikenal dengan sebutan paliasa secara empiris digunakan untuk pengobatan penyakit hati (kuning/hepatitis), kolesterol serta hipertensi. Selain itu juga berkhasiat sebagai obat gatal dan disentri. Potensi kimia K. hospita terlihat dari metabolit sekunder yang telah diisolasi, diantaranya adalah kaemferol dan quersetin yang diperoleh dari daun. Dengan aktivitas antiinflamasi dan antiviral (Soekamto, 2010)

\section{METODE PENELITIAN}

\section{BAHAN}

Bahan yang digunakan dalan penelitian ini adalah daun tahongai, etanol, aquades, $\mathrm{Na}-\mathrm{CMC}$, Na Diklofenak, karegenan, $\mathrm{NaCl}$ 0,9\%, pakan hewan

\section{PERALATAN}

Alat-alat yang digunakan dalam penelitian ini adalah kandang hewan, gelas kimia, pletismometerhot plate, timbangan analitik, rotary evaporator, timbangan hewan, inkubator, sonde oral, spoid, mortir dan stemperserta alat gelas penunjang lainnya

\section{PROSEDUR}

\section{PENGUMPULAN SAMPEL}

Daun tahongai (Kleinhovia hospita L) diperoleh dari perkebunan yang terletak di kelurahan Lempake, Kecamatan Samarinda Utara, Kota Samarinda, Provinsi Kalimantan Timur. Daun tahongai yang diperoleh disortasi untuk memisahkan daun dari bahan asing, kemudian dicuci dengan airmengalir, selanjutnya daun dipotong kecil kecil dan dikeringkan, daun yang telah kering kemudian disortasi kembali untuk memisahkan sampel dari pengotor.

\section{PROSES EKSTRAKSI SAMPEL}

Simplisia sebanyak 300 gram di masukkan ke dalam wadah maserasi, kemudian direndam menggunakan pelarut etanol sampai seluruh sampel terendam dan didiamkan selama 3 hari sambil sesekali diaduk, kemudian ditampung maserat dan dipekatkan menggunakan rotary evaporator sehingga diperoleh ekstrak kental, yang selanjutnya dikeringanginkan hingga diperoleh ekstrak kasar. 


\section{PEMBUATAN LARUTAN KARAGENAN 1\%}

Sebanyak 0,1 gram karagenan ditimbang, dilarutkan dalam larutan fisiologis $\mathrm{NaCl}$ sampai $10 \mathrm{ml}$ (larutan fisiologis $\mathrm{NaCl} 0,9 \%$ ).

\section{PEMBUATAN RADANG}

Radang dibuat dengan cara menginjeksikan sebanyak 0,1 ml larutan karagenin $1 \%$ secara subplantar pada telapak kaki tikus.

\section{PERSIAPAN HEWAN UJI}

Semua hewan uji dipelihara dengan kondisi yang sama. Sebelum digunakan hewan uji terlebih dahulu diadaptasikan dengan lingkungan penelitian. Kemudian sebelum diberi perlakuan hewan uji di puasakan selama 18 jam dengan tetap diberi minum

\section{PENGUJIAN EFEK INFLAMASI}

Tikus dikelompokkan ke dalam 5 keompok, yaitu kelompok kontrol negatif (Na$\mathrm{CMC}$ ), kontrol positif (Na Diklofenak), dan kelompok uji (dosis $250 \mathrm{mg} / \mathrm{kgBB}$, dosis 500 $\mathrm{mg} / \mathrm{kgBB}$ dan dosis $750 \mathrm{mg} / \mathrm{kgBB}$ ). tikus putih yang telah dipersiapkan untuk penelitian dipuasakan selama 18 jam dengan tetapdiberikan air minum.

Saat hari pengujian, masing-masing hewan uji ditimbang dan dibeti tanda pada kaki kirinya. Kemudian sediaan uji dioralkan pada masing masing hewan sesuai dengan pembagian kelompok, yaitu kelompok I diberikan Na-CMC, kelompok II diberikan natrium diklofenak , kelompok III diberikan ekstrak dengan dosis $250 \mathrm{mg} / \mathrm{kgBB}$, kelompok IV diberikan ekstrak dengan dosis $500 \mathrm{mg} / \mathrm{kgBB}$ dan kelompok $\mathrm{V}$ diberikan ekstrak dengan dosis $750 \mathrm{mg} / \mathrm{kgBB}$. Selanjutnya dilakukan pengukuran awal volume kaki tikus sebelum diinduksi dengan karegenan yang dinyatakan sebagai $\mathrm{V}_{0}$, Pengukuran dilakukan dengan mencelupkan kaki kiri tikus kedalam alat pletismometer, angka yang muncul dicatat sebafai volume awal. Telapak kaki tikus kemudian disuntik secara intraplantar dengan karegenan $1 \%$ sebanyak $0,1 \mathrm{~mL}$. Setelah 1 jam dilakukan pengukuran kembali dengan mencelupkan kaki tikus ke dalam alat pletismometer sampai mencapai tanda batas kaki tikus. Perubahan volume cairan yang terjadi dicatat sebagai volume telapak kaki tikus. Pengukuran dilakukan setiap 1 jam selama 9 jam

\section{HASIL DAN PEMBAHASAN}

Berdasarkan pengujian aktivitas antiinflamasi dengan menggunakan berbagai variasi dosis ekstrak etanol daun tahongai menunjukkan bahwa ekstrak daun tahongai memiliki aktivitas sebagai antiinflamasi. Hal ini dapat diketahu dengan membandingkan hasil kelompok ekstrak uji dengan kelompok kontrol negatif, dimana kelompok kontrol negatif semakin bengkak sedangkan kelompok ekstrak uji terjadi penurunan volume. Hal ini dapat terlihat pada gambar 1. 


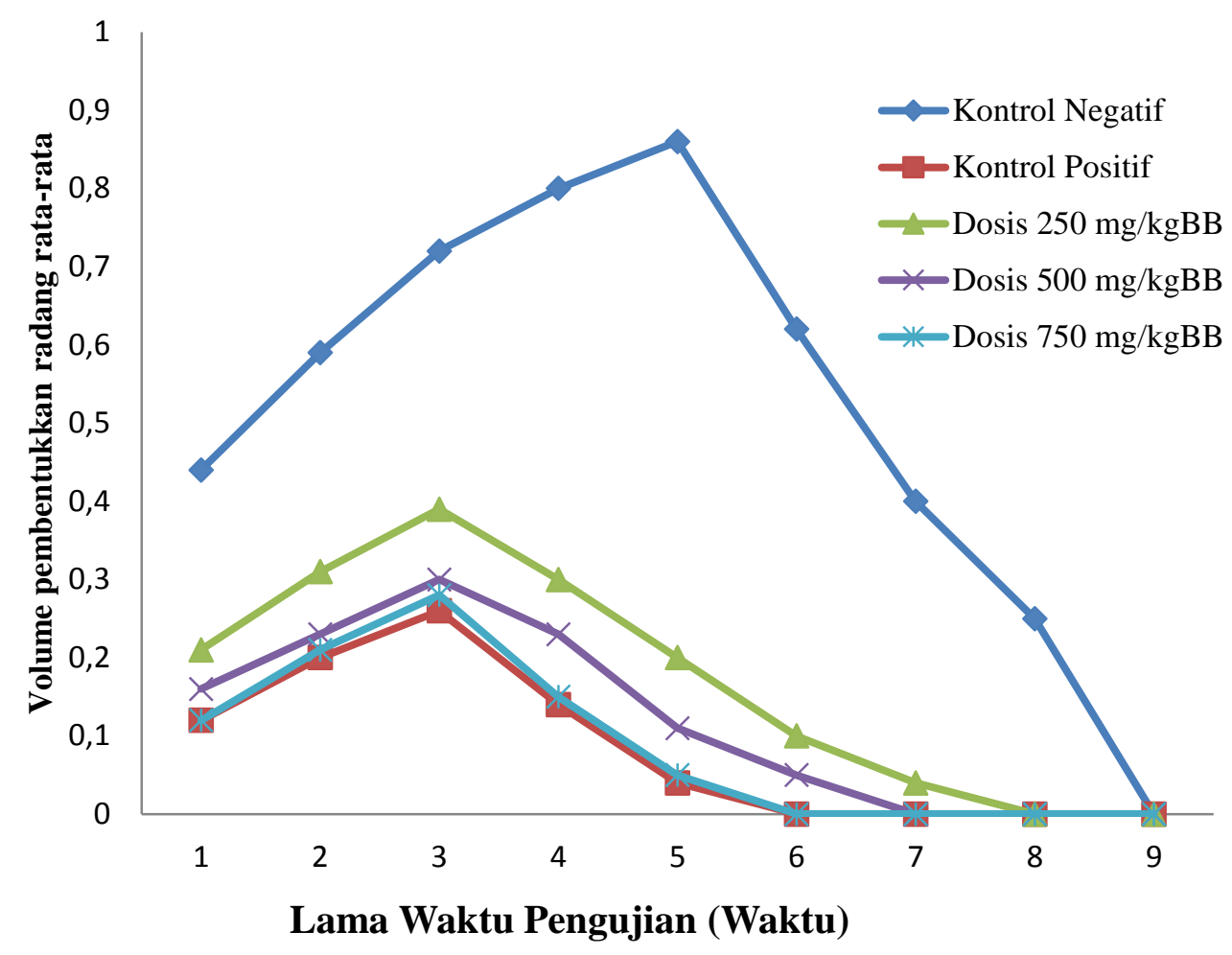

Gambar 1. Grafik Perbandingan VolumePembentukkanRadang Rata-Rata Pada Kaki Tikus Putih Kelompok Kontrol Negatif, Kontrol Positif Dan Dosis Ekstrak Daun Tahongai

Berdasarkan gambar 1 dapat dilihat bahwa pada kontrol negatif yang menggunakan suspensi Na-CMC semakin bengkak dari waktu kewaktu dimana waktu puncak inflamasi terjadi pada waktu 5 jam dan terlihat cenderung menurun pada waktu 6 jam, dan baru dapat mengembalikkan volume radang ke keadaan normal pada waktu ke 9 jam, adanya penurunan volume radang yang terjadi pada kelompok kontrol negatif diduga karena adanya mekanisme alami tubuh dalam menyembuhkan radang, sedangkan pengujian menggunakan dosis uji ekstrak yakni dosis $250 \mathrm{mg} / \mathrm{KgB}$, dosis $500 \mathrm{mg} / \mathrm{KgBB}$, dan dosis $750 \mathrm{mg} / \mathrm{KgBB}$, waktu puncak inflamasi terjadi pada waktu 3 jam dan cenderung menurun pada waktu 4 jam, dosis $250 \mathrm{mg} / \mathrm{KgBB}$ dapat mengembalikan volume radang ke keadaan normal pada waktu ke 8 jam, dosis $500 \mathrm{mg} / \mathrm{KgBB}$ dapat mengembalikan volume radang ke keadaan normal pada waktu ke 7 jam, dan dosis $750 \mathrm{mg} / \mathrm{KgBB}$ dapat mengembalikan volume radang ke keadaan normal pada waktu ke 6 jam.

Adanya aktivitas antiinflamasi ekstrak daun tahongai diduga karena adanya kandungan metabolit sekunder berupa flavonoid, dimana flavonoid mempunyai efek farmakologi dengan menghambat enzim siklooksigenase sehingga pembentukan mediatormediatornyeri seperti prostaglandin, bradikinin, histamin tidak terbentuk dan inflamasi tidak terjadi (Narayana, 2011)

Berdasarkan gambar 1. terlihat perbedaan aktivias antiinflamasi setiap kelompok uji. Kemudian dilakukan perhitungan presentase pembentukkan radang, hasil perhitungan tersebut dapat dilihat pada Tabel 1. 
Tabel 1. Persen (\%) Pembentukan Radang Rata-Rata Pada Kaki Tikus Putih Kelompok Kontrol Negatif Dan Ekstrak Daun Tahongai

\begin{tabular}{llllllllll}
\hline Kelompok uji & \multicolumn{7}{c}{ Persen (\%) pembentukan radang setiap satu jam (Vt) } \\
\cline { 2 - 10 } & $\mathrm{V}_{1}$ & $\mathrm{~V}_{2}$ & $\mathrm{~V}_{3}$ & $\mathrm{~V}_{4}$ & $\mathrm{~V}_{5}$ & $\mathrm{~V}_{6}$ & $\mathrm{~V}_{7}$ & $\mathrm{~V}_{8}$ & $\mathrm{~V}_{9}$ \\
\hline Kontrol Negatif & 44 & 59 & 72 & 80 & 86 & 62 & 40 & 25 & 0 \\
Dosis 250 mg/kgBB & 21 & 31 & 39 & 30 & 20 & 10 & 4 & 0 & 0 \\
Dosis 500 mg/kgBB & 16 & 23 & 30 & 23 & 11 & 5 & 0 & 0 & 0 \\
Dosis 750 mg/kgBB & 12 & 21 & 28 & 15 & 5 & 0 & 0 & 0 & 0 \\
\hline
\end{tabular}

Penentuan dosis terbaik dilakukan untuk mengetahui dosis paling baik ekstrak daun tahongai dari variasi dosis yang digunakan dengan parameter waktu paling cepat yang dapat menghambat radang sebesar $100 \%$.Berdasarkan perhitungan presentase pembentukkan radang pada Tabel 2., maka dapat dilakukan perhitungan presentase penghambatan radang yang terbentuk dari $\mathrm{V}_{1}$ hingga $\mathrm{V}_{9}$.Perhitungan persen penghambatan dilakukan untuk mengetahui besarnya penghambatan pada tiap waktu pengukuran. Hasil perhitungan dapat dilihat pada Gambar 2.

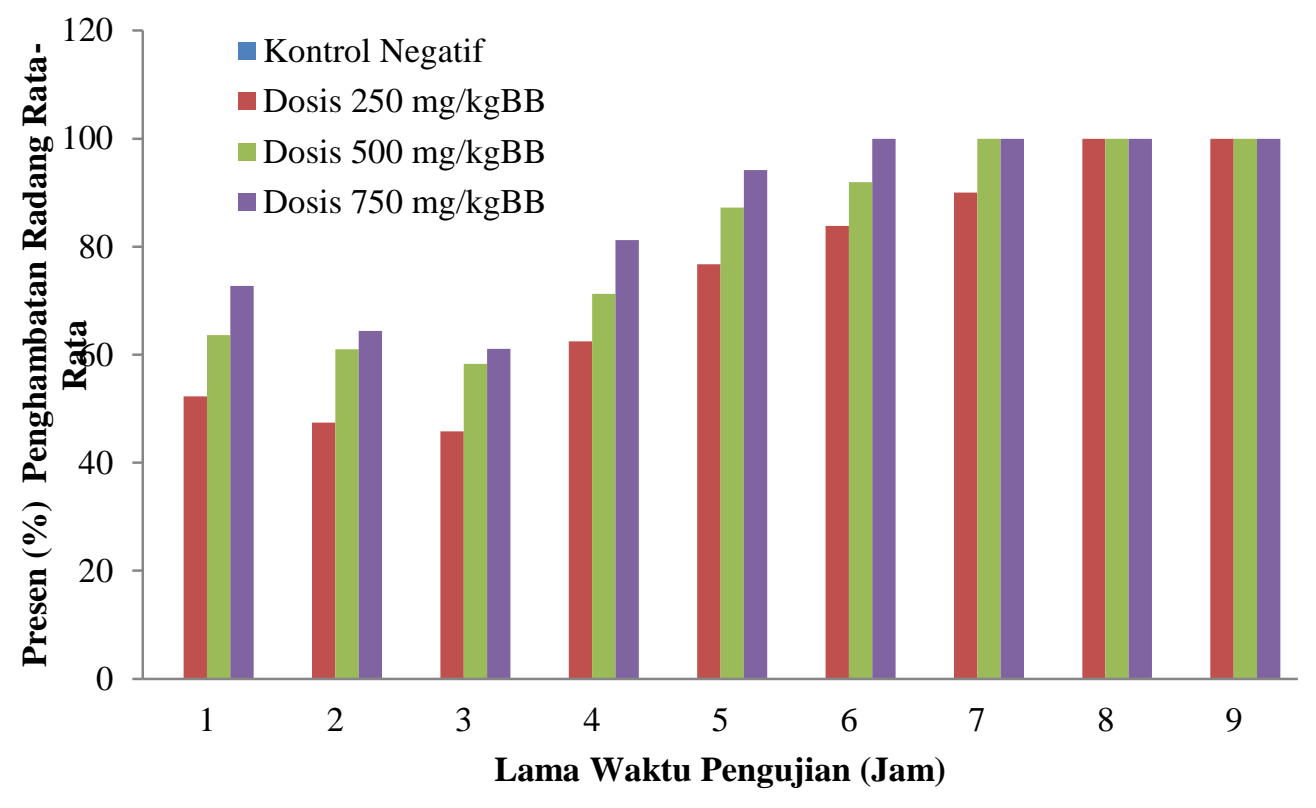

Gambar 2. Perbandingan Hasil Perhitungan Persen (\%) Penghambatan Radang Rata-Rata Pada Kaki Tikus Putih Kelompok Kontrol Negatif Dan Ekstrak Daun Tahongai

Berdasarkan Gambar 2. tersebut, menunjukkan ekstrak daun tahongai dengan tiga variasi dosis tersebut mampu menghambat radang pada kaki tikus putih dan pada dosis 750 $\mathrm{mg} / \mathrm{kgBB}$ adalah dosis yang memiliki waktu paling cepat yang dapat menghambat radang sebesar $100 \%$, dimana pada dosis tersebut dapat mengembalikkan volume kaki tikus ke keadaan normal sebelum diinduksi karagenan pada jam ke 6 , sedangkan dosis $250 \mathrm{mg} / \mathrm{kgBB}$ dapat mengembalikan volume kaki tikus ke keadaan normal pada jam ke 8 dan dosis 500 $\mathrm{mg} / \mathrm{kgBB}$ dapat mengembalikan volume kaki tikus ke keadaan normal pada jam ke 7 . 
Penentuan potensi antiinflamasi ekstrak etanol daun tahongai dilakukan dengan menggunakan kontrol positif berupa natrium diklofenak. Hasil dari pengujian natrium diklofenak yang kemudian dibandingkan dengan ekstrak etanol daun tahongai dengan dosis terbaik $750 \mathrm{mg} / \mathrm{kgBB}$. Hasil pengujian kedua kelompok tersebut tertera pada Gambar 3.

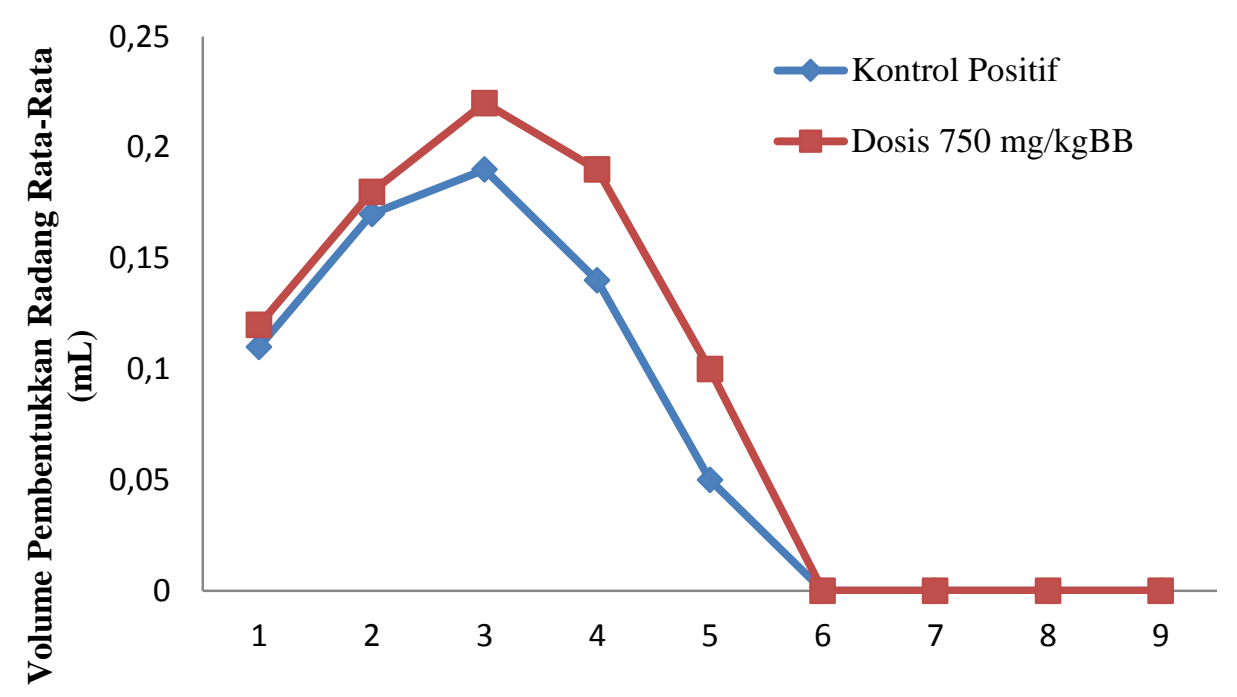

Lama Waktu Pengujian (Jam)

Gambar 3. Grafik Perbandingan Volume Pembentukkan Radang Rata-Rata Pada Kaki Tikus Putih Kelompok Kontrol Positif Dan Ekstrak Dosis 750mg/kgBB

Tabel 2. Persen (\%) Pembentukan Radang Rata-Rata Pada Kaki Tikus Putih Kelompok Positif Dan Ekstrak Dosis $750 \mathrm{mg} / \mathrm{kgBB}$

\begin{tabular}{llllllllll}
\hline Kelompok uji & \multicolumn{7}{c}{ Persen (\%) pembentukan radang setiap satu jam (Vt) } \\
\cline { 2 - 10 } & $\mathrm{V}_{1}$ & $\mathrm{~V}_{2}$ & $\mathrm{~V}_{3}$ & $\mathrm{~V}_{4}$ & $\mathrm{~V}_{5}$ & $\mathrm{~V}_{6}$ & $\mathrm{~V}_{7}$ & $\mathrm{~V}_{8}$ & $\mathrm{~V}_{9}$ \\
\hline Kontrol Positif & 12 & 21 & 25 & 14 & 5 & 0 & 0 & 0 & 0 \\
Dosis 750 mg/kgBB & 11 & 22 & 27 & 16 & 5 & 0 & 0 & 0 & 0 \\
\hline
\end{tabular}

Berdasarkan perhitungan persentase radang, maka dapat dilakukan perhitungan persentase penghambatan radang pada setiap kelompok. Perhitungan persen penghambatan dilakukan untuk mengetahui besarnya penghambatan ditiap waktu pengukuran. Hasil perhitungan dapat dilihat pada Gambar 4. 


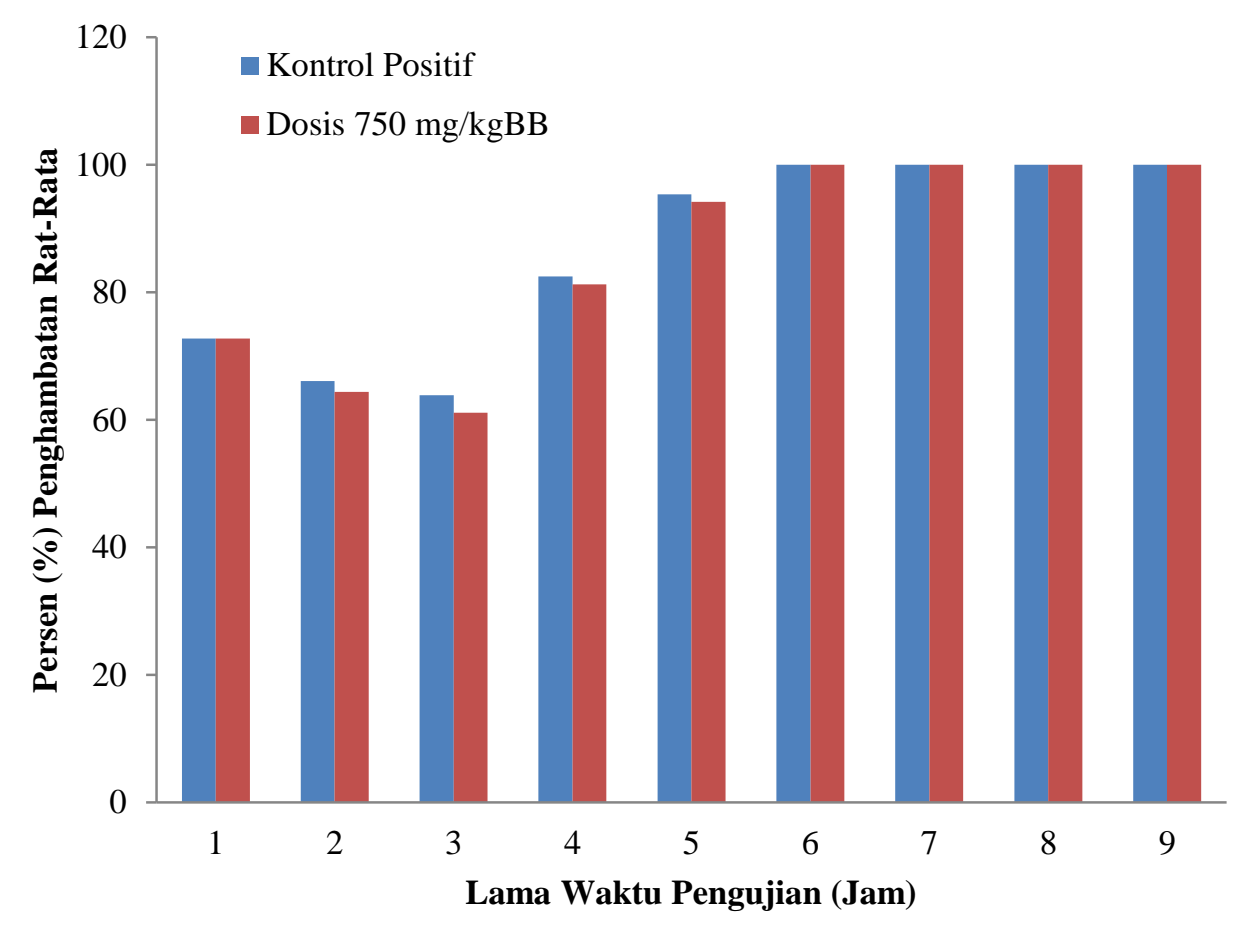

Gambar 4. Perbandingan Hasil Perhitungan Persen (\%) Penghambatan Radang Rata-Rata Pada Kaki Tikus Putih Kelompok Kontrol Positif dan Ekstrak Dosis 750 mg/kgBB

Kemampuan penghambatan radang yang terbentuk antara kedua kelompok uji (Gambar 4). Ditinjau dari mula penurunan $\left(\mathrm{V}_{1}\right)$ terlihat bahwa persen penghambatan pada natrium diklofenak lebih besar dibandingkan dengan ekstrak dosis $750 \mathrm{mg} / \mathrm{kgBB}$ namun demikian dilihat dari waktu keseluruhan terlihat bahwa kedua kelompok dapat menghambat radang sebesar $100 \%$ pada $\mathrm{V}_{6}$ atau dapat mengembalikkan volume kaki tikus ke keadaan normal. Berdasarkan hasil tersebut, maka dapat dikatakan bahwa potensi antiinflamasi ekstrak daun tahongai dosis $750 \mathrm{mg} / \mathrm{kgBB}$ hampir sama dibandingkan dengan kontrol positif natrium diklofenak.

\section{KESIMPULAN}

Berdasarkan hasil penelitian yang dilakukan maka dapat disimpulkan bahwa ekstrak etanol daun tahongai memiliki aktivitas antiinflamasi, dosis terbaik ekstrak daun tahongai sebagai antiinflamasi pada tikus putih adalah $750 \mathrm{mg} / \mathrm{kgBB}$ tetapi potensi ekstrak daun tahongai (Kleinhovia hospita $L$ ) hampir sama dibandingkan dengan kontrol positif natrium diklofenak.

\section{DAFTAR PUSTAKA}

Katzung, B. G.2002. Farmakologi Dasar dan Klinik edisi II. Salemba Medika. Jakarta

Kee J.L., Hayes E.R.,1996. Farmakologi Pendekatan Proses Keperawatan. EGC. Jakarta 
Mycek, M.J., Richard A.H. dan Pamela C.C. 2001. Farmakologi Ulasan Bergambar. Widya Medika. Jakarta.

Narayana, K. R., Reddy, M.R., Chaluvadi, M.R. 2001. Biovlafonoids, Clasification, Pharmacological, Biochemical Effect and Terapeutic Potential. Indian Journal Pharmacology

Wilmana, P.F. 1995. Analgesik-Antipiretik, Anti Inflamasi Nonsteroid dan Obat Pirai. Dalam Ganiswarna, S.G. 1995. Farmakologi dan Terapi. Edisi IV Bagian Farmakologi FK - UI. Jakarta 